\title{
MARKET REFORMS AND WATER WARS
}

\author{
By ERICA S. SIMMONS*
}

$\mathrm{D}$ URING the past thirty years, market-oriented economic reforms have swept much of the globe. Privatizations, free-trade agreements, the elimination of subsidies, and cuts in social safety nets have dominated economic policy agendas. Some communities have met increasing marketization with relative quiescence; some have voiced opposition along occupational or ethnic lines; and still others have come together across long-standing cleavages to mount widespread, broad-based movements in protest. Some scholarship expects a failure to mobilize in the face of market reforms, emphasizing the disorganizing, weakening, and/or atomizing effects of market-oriented economic policies on social movement or civil society organizations. ${ }^{1}$ Other approaches argue that market reforms can serve to repoliticize citizens. ${ }^{2}$ Neither perspective offers a fully satisfying account of the varied responses to such reforms. Understanding when and where resistance arises, when and where it does not, and what this resistance might be expected to look like remains underdeveloped.

This article asks two questions: (1) How can we better understand when marketization will or will not prompt resistance? And (2) when people do mobilize, why are some movements broad-based while others draw on particular segments of society? I argue that these questions

*I thank Celeste Arrington, Diego Ayo, Elisabeth Clemens, John Comaroff, Katherine Cramer, Carlos Crespo Flores, Santiago Daroca Oller, Timothy Pachirat, Sarah Parkinson, Kenneth Roberts, Frederic Schaffer, Rachel Schwartz, Dan Slater, Mariela Szwarcberg, Sidney Tarrow, Brianne Walsh, Lisa Wedeen, Deborah Yashar, attendees at the George Washington University Comparative Politics Workshop, the editors of World Politics, and the anonymous reviewers for their helpful assistance, comments, and feedback during the research and/or writing process. José Luis Enríquez provided valuable research assistance. I am grateful to the Fulbright Commission, the Tinker Foundation, the Mellon Foundation, the University of Chicago, and the Graduate School at the University of WisconsinMadison for financial support at various stages in the research and writing process. Earlier versions of this article were presented at the Latin American Studies Association annual congress and the American Political Science Association annual meeting. 2007.

${ }^{1}$ For example, Oxhorn and Ducatenzeiler 1998; Agüero and Stark 1998; Kurtz 2004; Auyero

2 For example, Edelman 1971; Polanyi 2001; Arce and Bellinger 2007; Silva 2009.

World Politics 68, no. 1 (January 2016), 37-73

Copyright (C) 2015 Trustees of Princeton University

doi: $10.1017 /$ S0043887115000337 
can best be answered by focusing not only on the political contexts and resources available to potential social movements, but also on what is perceived to be at stake during marketization. These perceptions influence mobilization processes and the kinds of groups available for mobilization. When people understand markets as threatening to material wellbeing as well as to widely shared community relationships, understandings, and commitments, heightened feelings of group belonging can contribute to broad-based mobilization. My approach is in line with efforts to focus attention on the mechanisms at work during contentious episodes ${ }^{3}$ and to look to composite causal contingencies in mobilization processes. ${ }^{4}$ It is distinguished from dominant theorizing on social movements because it emphasizes the importance of the grievance, ${ }^{5}$ and in doing so helps to "pluralize understandings of the microfoundations of contentious politics." It also builds on classic approaches to relationships between markets and mobilization, ${ }^{7}$ advancing them by explicitly incorporating actors' symbolic claims.

Economic relationships, processes, and practices cannot be divorced from the ideas with which they are imbued. Markets create very real material effects, but they are also constituted by the ideas we have about them and the ideas we have about the goods they regulate. Analysis of responses to marketization needs to incorporate the ways in which processes of grievance interpretation influence mobilization. ${ }^{8}$ Different material goods take on different meanings in different times and places, and those meanings influence whether or not people mobilize to oppose marketization and what that mobilization looks like. ${ }^{9}$ Political context and resources undoubtedly play a role in mobilized responses to markets, but attention to the ways in which people interpret their social and economic worlds (and an understanding of the two as inextricably intertwined), can improve analysis of why some market reforms generate resistance and why that resistance looks the way it does.

This article looks at the way some goods help to produce or reproduce conceptions of community. It theorizes that these goods may serve as particularly powerful "mobilizing grievances,"10 creating the conditions

${ }^{3}$ For example, McAdam, Charles, and Tilly 2001.

${ }^{4}$ Lofland 1996; Loveman 1998.

${ }^{5}$ See Simmons 2014 for a full discussion of a meaning-laden approach to grievances.

${ }^{6}$ Pearlman 2013.

7 For example, Thompson 1971; Scott 1976; Polanyi 2001.

${ }^{8}$ Snow et al. 1986.

${ }^{9}$ Following John Comaroff, I take meaning to be "the economy of signs and symbols in terms of which humans construct, inhabit, and experience their social lives (and thus act in and upon the world)," cited in Wedeen 2009, 81-82.

10 Snow and Soule 2010. 
of possibility for broad-based resistance. The article develops the argument through analysis of mobilizations against water privatization in the valley of Cochabamba, Bolivia, in 1999 and 2000-events that came to be known as the water wars. ${ }^{11}$ The privatization contract brought Bolivians from every class, occupation, age, and ethnicity to the streets. Cochabambans for whom the average 60 percent rate increase for water due to privatization was an economic hardship joined others who could easily pay their increased bills and still others who were not connected to the municipal water network at all. Although market reforms in Bolivia began almost fifteen years earlier, and opposition to them was not new, the protests in Cochabamba grew to an unprecedented scope and scale. Mobilization cut across long-standing urban-rural divides as well as across preexisting class, sectoral, and ethnic cleavages. Why did this mass protest occur when it did, and why was it so diverse?

The Cochabamban case provides tools to develop new theoretical insights into why mobilization occurs when it does and why it takes the forms it does. This article focuses specifically on the emergence and composition of a movement in its early months. The first stages of resistance in Cochabamba show that what is being marketized matters for patterns of political protest. The case also suggests that to know what is getting marketized, the process needs to be embedded in its specific cultural context. It is impossible to understand the dynamic growth and broad-based composition of the resistance movement in Cochabamba without taking into account the ways in which water symbolized community for Cochabambans across social and economic classes, and how, as a result, privatization could be perceived as a threat to communities as small as neighborhoods and as large as the Bolivian nation. Highly localized perceptions of water intersected with insecurities rooted in marketization to help generate political resistance. What water meant to Cochabambans and in particular, the ways in which it indexed different, sometimes overlapping communities throughout the region, mattered in the mobilization process.

Analysis of the Cochabamba case does not provide sweeping general arguments that map neatly onto every instance of mobilization and quiescence in the face of market reforms. Indeed, part of what the case highlights is the ways in which responses to markets are highly conditional and contingent. But the case offers important theoretical insights that inform how patterns of resistance to mobilization are ex-

${ }^{11}$ Some accounts of these events describe them as the "water war" in the singular. I adopt the plural "water wars" because there were multiple protest events in January, February, and April 2000, each of which can be understood as its own war. See Appendix 2 for a timeline. 
plained and understood. It allows us to explore the kinds of conditions under which surprising coalitions are forged and the ways in which the potentially atomizing effects of neoliberalism might be overcome. The case shows that to understand how and why people respond to markets the way they do, the material and the symbolic must be understood as inextricably intertwined.

\section{Conceptions of Community, Marketization, and Mobilization}

The potential for theorizing connections between perceived community threats and mobilization is clear in cases as varied as antinuclear protests in the United States, indigenous mobilizations in Latin America, and uprisings in post-Mubarak Egypt. Rogers Brubaker urges us to understand these communities as a "category of practice" that does not always function with the attributes of a group. ${ }^{12}$ Yet dramatic events can "galvanize group feeling, and ratchet up pre-existing levels of groupness." 13 Marketization of a good that has come to symbolize community may tap into preexisting connections to particular groups and bring those connections to the fore, rendering them more powerful in the face of the market-driven threat. ${ }^{14}$

Market-oriented policy reforms might be understood as threats to a variety of different communities in a variety of ways. For example, markets can come with new citizenship regimes that directly threaten particular communities' practices of self-governance. ${ }^{15}$ They may also transform particular sectors of the economy and lead to perceptions of threat to community among the affected workers. ${ }^{16}$ These kinds of threats might prompt resistance limited to a particular category of identification or to a particular sector (for example, indigenous groups and miners, respectively). It is easy to grasp how the sale of the national mines might have been seen as a threat to understandings of self and community among Bolivian miners who mobilized as a result. A theoretical approach that focuses on the ways in which marketization is perceived as a threat to community may help us to better understand how and why some mobilizations draw primarily on one category of identification.

This approach can also help us to understand when market reforms

${ }_{12}$ Brubaker 2004.

${ }_{13}$ Brubaker 2004, 14.

${ }^{14}$ Identifications are also often constructed and reproduced through the very act of participating in social mobilization (see, for example, Calhoun 1991; Gould 1995).

${ }^{15}$ For example, Yashar 2005.

${ }^{16}$ For example, Gill 2000. 
might generate not just mobilization within a particular group, but also broad-based resistance-precisely the question that the Cochabamba case highlights. Some goods help to construct quotidian communitiescommunities built on face-to-face, routine interactions where members know each other personally. ${ }^{17}$ The same goods might help to construct different kinds of quotidian communities throughout a particular region. In Cochabamba, quotidian communities emerged through efforts to secure a water supply to areas not connected to the municipal water network, through governance of irrigation systems, and through professional associations working to overcome regional shortages, to name a few. But even as they construct face-to-face communities, some goods also help to construct the "imagined communities" of nation, region, or ethnic group. ${ }^{18}$ These goods can serve as a symbol of national belonging, a vehicle through which particular regional identifications are reproduced, or as a way of indexing membership in an ethnic category of identification. In Cochabamba water symbolized region, nation, and Andean heritage, among other things. When whatever is being marketized symbolizes imagined and/or quotidian communities that reach beyond particular occupational, sectoral, or class categories, perceived threats to community can cross cleavages and create the conditions of possibility for broad-based mobilization.

This argument builds on Karl Polanyi's famous claim that commodification of the fundamental bases of production should result in the emergence of a "double movement"- a movement to protect citizens from the dangers of unregulated markets. ${ }^{19}$ At the core of the argument is Polanyi's concept of "embeddedness"- the idea that markets cannot be understood or analyzed as distinct from the communities in which they form. For Polanyi, "man's economy, as a rule, is submerged in his social relationships." ${ }^{20}$ When markets threaten those relationships, movements call on the state to intervene and regulate capitalism. Yet this kind of widespread mobilization was strikingly absent in the early decades of neoliberal reform. ${ }^{21}$ Furthermore, even when mobi-

\footnotetext{
17 Simmons 2014. The quotidian community concept has some resemblance to Ferdinand Tönnies' concept of "Gemeinschaft" insofar as the term refers to ties based on relationships developed through direct, person-to-person contact (Tönnies 1988). See also Gudeman 2001, 1, for a discussion of the ways in which economic practices help to create what he calls "on-the-ground associations" in addition to imagined solidarities.

18 Anderson 1991. Imagined communities are constituted by individuals who may never meet one another face-to-face. They develop connections mediated by, for example in Anderson's argument, print capitalism, and have affinities for members even in the absence of direct, personal communication.

19 Polanyi 2001. Other authors have explored the connections between Polanyi's claims and resistance to market reforms in contemporary Latin America. In particular, see Silva 2009.

20 Polanyi 2001, 48.

21 For example, Fraser 2013.
} 
lization took place it often looked decidedly different from Polanyi's double movement. The Cochabamba case presents a striking example. While the movement rejected placing control over water in the hands of a private company, it also explicitly rejected state interference in local affairs. Furthermore, organized labor-a central force in the double movements of Polanyi's argument - acted largely in cooperation with a host of other groups.

Yet Polanyi's insistence that markets be analyzed as socially embedded remains critical. Even as markets play a role in how goods are obtained or wages earned, consumption and labor practices remain highly social acts. ${ }^{22}$ To understand contemporary mobilization processes, we need to embed markets in their social contexts. Although the workplace has not been rendered obsolete as a location of resistance, individuals and groups have discovered, created, and strengthened new forms of collective identification that serve as effective centers of protest in the context of a globalized, neoliberal world. ${ }^{23}$ Communities are produced and conceptualized in new places and ways. When the factory falls away, it is logical to imagine that groups will find security in neighborhood-level relationships designed to provide for daily material and social needs, or in pride in national heritage or culture. When these (sometimes) newfound loci for collective identification are threatened by the unpredictability and insecurity of markets, resistance could be particularly powerful.

We know that in some cases markets have demobilized and fragmented labor and, more broadly, depoliticized and atomized society. But we also know that many populations have mobilized to fiercely resist neoliberal reforms. When we break from essentialist accounts of responses to neoliberal reforms, we can see how market liberalization might simultaneously demobilize and fragment popular sectors, ${ }^{24}$ receive high levels of popular support, ${ }^{25}$ and stimulate social protest in defense of popular interests. ${ }^{26}$ The Cochabamba case helps to reconcile this long-standing debate by focusing us on the ways in which the effects of markets are contextual, conditional, and highly contingent. Certain types of grievances can become a focal point around which diverse social actors with widely varying interests can unite. ${ }^{27}$ In places

${ }_{22}$ Friedman 1990, 314, observes that "consumption within the bounds of the world system is always a consumption of identity, canalized by a negotiation between self-determination and the array of possibilities offered by the capitalist market."

${ }^{23}$ See Eckstein and Wickham-Crowley 2003.

${ }^{24}$ For example, Kurtz 2004.

${ }^{25}$ For example, Bakker 2009.

${ }^{26}$ For example, Arce and Bellinger 2007; Silva 2009.

${ }^{27}$ Simmons 2014. 
where neighborhood ties or other associational structures are strong, communities are available to be mobilized if they perceive that they are being threatened. Particular types of grievances may tap into these associational structures, bringing together diverse constituencies, fostering coalition-building processes, and ultimately overcoming the societal fragmentation that Marcus Kurtz and others feared. ${ }^{28}$ Depending, in part, on what people perceive to be at stake, markets can demobilize and depoliticize and generate significant popular opposition.

The Cochabamba case shows how the structural dynamics at work in Polanyi's analysis are only one piece of the analytical puzzle. The protesters' place in the structure of the capitalist system mattered in their response to marketization, but so too did their conceptions of indigenous heritage, national belonging, and communal reciprocity. Collective imaginings around region, nation, and ethnicity were critical to the Cochabamba movement, and they were available to movement organizers because of the ways in which water indexed community to Cochabambans across class, ethnic, and regional divides. A focus on how people might perceive their community to be at stake during marketization processes offers useful insights into the relationship between markets and social movements, deepening our understanding of what a contemporary double movement might look like and exposing the limitations of arguments that are over-reliant on economic structures.

\section{WATER IN COCHABAMBA}

In Cochabamba, water helped to resolve what had been, in Thomas Schelling's terms, a coordination problem. ${ }^{29}$ Water emerged as a focal point, something that brought together diverse groups with diverse interests to fight for a common goal. For many Cochabambans, water helped to produce and reproduce conceptions of regional rights and communal identity, regardless of their occupation or place of residence within the valley. Many Cochabambans shared an understanding of water as a symbol of something more than its biophysical characteristics. Water was tied to local and regional identities through irrigation practices, an agricultural past, and extended struggles with scarcity. Yet, not surprisingly, the meanings that water took on in Cochabamba were varied and sometimes contradictory - the particularities differed according to time, place, and person. Still, the privatization contract

28 Oxhorn and Ducatenzeiler 1998; Agüero and Stark 1998; Kurtz 2004.

29 Schelling 1960. 
evoked resistance rooted in broad community needs and relationships that were expressed in familiar, long-standing discourses.

In Cochabamba water signified the imagined communities of nation, region, and ethnic group, and quotidian communities built on faceto-face interaction. As people anticipated that established community routines and centers for social interaction would be altered, the foundations of social structures and interactions were perceived to be at risk. The threat of water privatization tapped into imagined and quotidian identifications, heightening solidarity by bringing to the fore common relationships with the threatened resource. Individuals at odds over salient local divisions (for example, class, sector, occupation, gender, ethnicity, or geography - urban, peri-urban, and rural) coalesced around the perception of the shared threat. The "material and symbolic urgency of water," 30 the way in which it indexed community to Cochabambans with both disparate and overlapping identifications, allowed frames deployed during the water wars such as, "the water is of the people," or "the water is ours, damn it," to both negotiate new meanings and to be faithful to longstanding narratives. ${ }^{31}$ These slogans summoned a "we" into being in the very moments they were uttered or written, creating a large collective based on preexisting categories of belonging and the perceptions that those communities might be at risk.

The analysis that follows allows me to make particular claims about the events in Cochabamba and to advance propositions about the ways in which resistance to markets might be particularly likely when conceptions of community are at stake. The purpose of this article is not to explain all variation in response to markets in Bolivia, Latin America, or beyond. Instead, the purpose is to show that what people perceive to be at stake in marketization processes matters for mobilization and that perceived market-driven threats to community might serve as particularly powerful mobilizing grievances. Attention to the ways in which some ideas or things may index community in particular times and places help us to better understand the advent and dynamics of resistance to markets.

30 Albro 2005, 255.

${ }^{31} \mathrm{I}$ am not proposing that every movement leader or participant mentioned in the pages that follow was motivated either partially or entirely by the variety of community-related meanings of water. A host of other factors were undoubtedly at work, as leaders and participants saw the movement through opportunistic lenses. Yet water provided the grievance around which various interests could unite, even if it was understood to be a vehicle and not an end in itself. 


\section{Methods And Data}

The scope and scale of the mobilizations in Cochabamba during the water wars were without precedent in the neoliberal era. As a result, this single case study creates the possibility for new theorizing about the mechanisms at work during contentious processes. The Cochabamba case also allows me to focus on the intersection of micro- and mesolevel factors and to explore how contested meanings at the microlevel can actually work as the foundation for shared mesolevel meanings as a movement emerges. Within-case variation in meaning-making processes around water highlights the ways in which divergent practices and ideas can converge in a single mobilization process. The single case also allows me to endogenize temporally grounded and regionally rooted perceptions of Bolivia's policy-reform process. ${ }^{32}$

The emphasis on theoretical innovation and attention to processes and mechanisms admittedly comes at the expense of sub- or crossnational hypothesis testing. ${ }^{33}$ But that kind of testing is not the aim of this analysis. Instead, by exploring the Cochabamba is case, I examine the relationship among markets, perceptions of community, and social mobilization, and shed light on dynamics that are easily overlooked when aiming to select representative samples or trying to avoid selecting on the dependent variable. ${ }^{34}$ While meanings are indexed to particular situations, examining how they work in mobilization processes can add to theoretical models of the dynamics of contention.

This article is a work of both interpretive ethnography and interpretive historical analysis. ${ }^{35}$ I conducted six months of fieldwork in Bolivia in 2008 and in 2010, and extensive historical research. The research included ethnographic fieldwork, over 100 open-ended and semistructured interviews, and close readings of texts produced prior to and during the water wars. ${ }^{36}$ The approach is well-suited to the questions at hand for three reasons. First, by enmeshing myself in the world I sought to study, I hoped to better understand what particular actions, words, or other symbols might mean to the Cochabambans with whom I interacted. I was able to explore the ways in which practices that have never

32 George and Bennett 2005.

${ }^{33}$ George and Bennett 2005; Gerring 2007.

${ }^{34}$ Small 2009.

${ }^{35}$ For descriptions of interpretive social science see Rabinow and Sullivan 1987; Schwartz-Shea and Yanow 2012; Wedeen 2009.

${ }^{36}$ For a good discussion of the difference between interpretive and noninterpretive ethnography, see Wedeen 2009. 
been "put to paper"37 order daily lives and are rendered meaningful. Second, I was able to avoid individualist assumptions about the logics of collective action and instead to treat actors as socially embedded. ${ }^{38}$ This allowed me to explore questions about the ways in which communities were constituted and how the water privatization contract might be perceived as a threat to them. Third, the combination of interpretive ethnography and historical analysis allowed me to explore meaningmaking processes at the micro- and mesolevels. The two approaches helped me to understand how participants in the water wars made sense of the world around them and how those meanings interacted with the meaning-making processes of Cochabambans from various neighborhoods, classes, or professions. ${ }^{39} \mathrm{I}$ explored the effect that language and symbols had in various Cochabamban contexts, tacking between what I observed during fieldwork and in accounts of daily life in Cochabamba before and during the water wars. The ability to move between neighborhoods and across time not only brought to the fore the ways in which the particularities of water's meanings varied, but also often remained consistent with a broader narrative of community autonomy and dignity. See Appendix 1 for additional information on data and methods.

\section{The ConTEXT}

Suffering from large foreign debt, negative gross domestic product (GDP) growth, and inflation that reached 8,170 percent in early 1985, Bolivia seemed the perfect test case for the package of economic adjustments that would become known as the Washington consensus. Bolivian President Víctor Paz Estenssoro initiated the New Economic Policy (Nueva Política Económica, NPE) that year, reducing trade barriers, cutting public expenditures, devaluing the currency, and privatizing national industries. Throughout the 1990s, Paz Estenssoro's successors deepened their commitment to market-oriented economic reforms. ${ }^{40}$

The Bolivian government initiated the privatization of the Cochabamban water system in 1997 with the announcement that the Cochabamba Municipal Drinking Water and Sewage Service (Servicio

37 Parkinson 2013, 420.

${ }^{38}$ Wedeen 2002.

${ }^{39}$ See Cramer Walsh 2012 for an excellent example of how participant observation can shed light on how people make sense of their worlds.

${ }^{40}$ Jaime Paz Zamora (1989-93) further reduced public sector employment and passed legislation permitting the privatization of most remaining public sector firms (Grindle 2003). President Gonzalo Sánchez de Lozada (1993-97) pursued additional privatization policies. 
Municipal de Agua Potable y Alcantarillado de Cochabamba, SEMAPA), the Cochabamban municipal water company, would be offered to private bidders. The final contract granted the firm Aguas del Tunari a forty-year concession and what amounted to monopoly rights over the region's water. ${ }^{41}$ Law 2029, signed by President Hugo Banzer on October 29, 1999, legitimized the contract and granted the firm private control to any wells that had been locally paid for, built, or managed. ${ }^{42}$ On November 1, Aguas del Tunari assumed management of community-based water resources and residents were expected to pay accordingly. By January 2000, large-scale protest had begun, and by April the government was forced to renationalize Cochabamban water. Although protest quickly subsided, the Cochabamban movement initiated a period of political unrest that drove presidents from office and helped propel Evo Morales to the presidency five years later.

The water wars were not the first time Bolivians took to the streets in the neoliberal era. A movement emerged in the Amazon in the early 1980s that focused on concerns of indigenous autonomy and territory. ${ }^{43}$ The indigenous movement garnered significant national attention in 1990 with a March for Territory and Dignity, which helped to secure a number of indigenous territories via executive decree. In 1985 and 1986, Bolivian unions mounted powerful opposition to the NPE but were quickly demobilized by a state of siege. In 1994 coca growers mobilized to resist Gonzalo Sánchez de Lozada's Zero Coca plan, coordinating a roughly 560 kilometer "March for Life, Coca, and National Sovereignty" that began in Villa Tunari and ended in La Paz. ${ }^{44}$ Teachers took to the streets in large numbers to protest education reform in $1995 .{ }^{45}$ Road blockades occurred regularly throughout the country, and residents of La Paz and El Alto repeatedly demonstrated their ability to shut down both cities for twenty-four-hour paros (stoppages) to draw attention to any number of issues, from garbage collection to road construction.

With the mobilizations in Cochabamba, however, the patterns of resistance changed. Blockades were not singular events but rather part of a sustained series of actions coupled with massive street mobilizations. Furthermore, protesters represented a variety of different social, oc-

\footnotetext{
${ }^{41}$ Protesters discovered that Aguas del Tunari was a subsidiary of the American company Bechtel in March, after the movement was well underway. US involvement, therefore, does not offer a plausible account of the early mobilizations on which this article focuses.

${ }_{42}$ The contract required changing Bolivian law (the passage of Law 2029).

${ }^{43}$ See Yashar 2005.

44 Yashar 2005.

${ }^{45}$ See Gill 2000.
} 
cupational, class, and ethnic categories. The lack of mobilization along ethnic lines is particularly noteworthy given the mobilizing around indigenous issues that had recently occurred in the country. While more than half of the Department's ${ }^{46}$ population self-identified as Quechua - an Andean indigenous ethnic category - at the time, particular ethnic identifications were largely encompassed by a broader category of Andean belonging, an association that was easily available to urban and rural groups, regardless of their ethnic identification. The coalitions that emerged during the water wars cut across long-standing cleavages and sociopolitical divisions and united former adversaries at protest meetings, events, and negotiations.

\section{Regional Identifications and Professional Mobilization}

A small group of urban professionals quickly mounted opposition to the Aguas del Tunari contract. ${ }^{47}$ This group, officially called the Committee for the Defense of Water and the Popular Economy (Comité de Defensa del Agua y la Economía Popular, CODAEP) ${ }^{48}$ emerged as a result of a shared interest in and understandings of water across Cochabamba's professional communities. Most of CODAEP's founders were environmentalists, engineers, teachers, lawyers, and economists, and were comfortably situated in the middle class. Most members could endure a rate increase without having to make material trade-offs. The "point of recognition" 49 that brought them together was the shared experience of fighting for improved water management and access and the conception that privatization meant more than a potential increase in water bills. The conception that the contract undermined an extended local effort to establish a sustainable regional water supply was similarly shared. ${ }^{50}$

Cochabamba's seasonal water shortages had long served as the focus of public and private debate. Cochabamban professionals and policymakers had been researching and advocating for, as well as fighting over, various solutions to the region's limited access to water for nearly fifty years. The Misicuni Multipurpose Project, also known as the Misi-

\footnotetext{
${ }^{46}$ Departments are the largest subnational political units in Bolivia, resembling states in the US context or provinces in Canada.

${ }^{47}$ See Simmons 2014 for a discussion of some of the Cochabamba data in service of a general argument for a meaning-laden approach to grievances.

${ }_{48}$ Also called the Committee for Defense of Water and the Family Economy.

49 Albro 2005.

${ }^{50}$ Water also has a powerful national significance rooted in Chile's loss of access to the sea during the War of the Pacific. These discourses, however, do not appear to have featured prominently during the water wars.
} 
cuni Dam or just Misicuni-an extensive construction project proposed to help alleviate water shortages-was debated and discussed by the Cochabamban division of the Engineers' Society of Bolivia and by the mayor's office for almost two decades. Corruption within SEMAPA was front-page news. Conversations revolved around water during the dry season. Quotidian communities of individuals working on and concerned about the future of water in Cochabamba formed. Some of these were limited to particular interests or professions (for example, environmentalists or lawyers), while others crossed sectoral or interest lines to create spaces for broad conversations about water-related challenges. Together, these quotidian communities constituted a larger epistemic community of Cochabamban professionals with common water-related concerns and experiences.

Contemporary drought, combined with idealized notions of a verdant, paradisiacal past, heightened water's role in the Cochabamban imaginary. ${ }^{51}$ Understandings of water intersected with connections to land and agriculture. Water took on meanings, in part, because of the ways in which it shaped daily life and practice and because of the way it gave life to crops. Indeed, early access to water in Cochabamba "helped turn the region into the breadbasket of the country, fueling Bolivia's growth by providing grains to the miners that drove the country's development through both the silver and tin mining booms." ${ }^{2}$ Cochabambans spoke of this role with nostalgia; the region's history of cultivation produced notions of regional self-worth, and recollections of it were infused with regional pride.

CODAEP founders consistently discussed the importance of water in their personal and professional lives. Engineer Antonio Siles remarked, "We had been the breadbasket of the country. Of course water was central in our lives ... [W] hen they published the [Aguas del Tunari] contract the Engineers' Society had to do an evaluation. And it was simply a bad project. After all these years, we deserved a better project." ${ }^{3}$ The extended struggle for water made conceptions of what the region "deserved" particularly powerful. Because Cochabamba had used its water for so many years to fuel the country and the region had suffered disproportionately under the NPE, it now deserved better when it came to water. ${ }^{54}$ By not meeting expectations for water service provision, the

\footnotetext{
51 See Larson 1998 for a detailed history of the region, including attention to water and agricultural practices.

${ }_{52}$ Simmons 2014, 535. On the silver boom and agricultural production in Cochabamba, see Larson 1998.

53 Author interview with Antonio Siles, January 28, 2010

${ }^{54}$ Simmons 2014.
} 
state had failed to deliver on a promise to the region's residents. The state's inability to meet perceived obligations helped to produce notions of entitlement grounded in region and divorced from the particularities of class or sector.

These common understandings translated into collaboration. Water became an issue around which middle- and upper-class groups that had often opposed each other over water policies in the past could easily unite. For Siles it was about the technical quality of the project itself. For CODAEP founder Gabriel Herbas, it was about the environment. The valley's search for water had raised environmental concerns, and groups had formed to evaluate the potential Misicuni project and advocate for sustainable water policies. ${ }^{55}$ Engineers and environmentalists might have understood the implications of the privatization contract differently, but they were able to come together for the larger political project of mobilized resistance. Lawyer and water wars activist Victor Gutierrez recalled, "I knew it could be big. Campesinos [peasants], regantes [irrigators], families in the city-everyone cared about water. Maybe for different reasons, but it was important to everyone." ${ }^{56}$ Water symbolized community to different people in different ways, yet these differences could be contained within broad mobilization frames such as "the water is ours." As such, separate mobilization identifications could coalesce at the mesolevel without threatening participants' individual conceptions of what was at stake.

\section{Bridging the Urban-Rural Divide}

With the passage of the legal prerequisite for the Aguas del Tunari contract, Law 2029, in October 1999, the resistance movement expanded. On October 27, one day prior to the law's passage, the Cochabamba Federation of Irrigators (Federación Departamental de Regantes de Cochabamba, FEDECOR) joined CODAEP in Vinto, a Cochabamba suburb, to block the highway connecting Cochabamba to Oruro and La Paz - a central national artery - and to demand the repeal of the law.

The cooperation between urban Cochabambans, many of whom had migrated to the region in the wake of the privatization of the mines in the mid-1980s, and rural groups is particularly noteworthy. Urban-rural differences, both in policy preferences and organizational structuresran deep. ${ }^{57}$ The "war of the wells" had brought the two sectors into conflict only a few years earlier; water's contested meanings, including

\footnotetext{
55 Author interview with Gabriel Herbas, September 3, 2008.

56 Author interview with Victor Gutierrez, January, 21, 22, and 26, 2010.

57 See Cusicanqui 1990; Spronk 2007.
} 
the different ways in which it worked to help produce communities in urban and rural areas, had generated contention over the policies and procedures for well drilling. Prior to 1999, cooperation among these groups, particularly on the scope and scale seen during the water wars, was largely unprecedented.

Yet even as the blockade bridged regional divisions, it also literalized the divide between Cochabamba and the nation's functional capital. This common contemporary protest tactic cut off all road travel and commerce between Cochabamba and La Paz. The blockade was a physical manifestation of the ideational divide between the valley's inhabitants and the officials in La Paz who had made, and would continue to make, policies with little understanding of local meaning and practice. Urban and rural understandings of and relationships with water were both recognized and contained in the regional identifications that brought Cochabambans together to resist the Aguas del Tunari contract.

\section{Usos y Costumbres AND “THE” AndeAn Cosmovision}

For regantes, the contract and Law 2029 threatened imagined and quotidian communities in fundamental ways. Many perceived their well-established practices for constructing, regulating, and monitoring rural irrigation systems to be at risk. This served as a direct threat to quotidian communities, challenging both the strong professional ties that had formed through daily work and the ties that were produced through FEDECOR itself. FEDECOR President Omar Fernández recalled, "From the start we were worried about how we would be affected. And then we learned more. We saw that usos y costumbres [traditions and customs] were not being respected, that they weren't even a part of the contract. So we knew we had to act." 58

Usos y costumbres vary throughout the Cochabamba valley, yet they consistently refer to physical practices surrounding water use and management and broader claims of perceived water rights, autonomy, or self-governance. In rural and peri-urban settings, both areas where irrigation practices are common, usos y costumbres might refer to a particular community's specific rules governing who has access to how much water and when. Water is the fundamental organizing principle for many rural and peri-urban communities. Complex and highly structured systems of obligations, rights, responsibilities, and justice govern relationships with water sources. Through these processes, water

58 Author interview with Omar Fernández, September 3, 2008. 
produces and reproduces quotidian communities, serving as the raison d'être for governance structures and regular communal interactions.

Usos y costumbres not only help to organize systems of water use, but also serve as a "cultural signifier" 59 that often suggests a highly essentialized conception of Andeanness and indigeneity. The concept is grounded in a connection to the past - many Cochabambans, irrigators and otherwise, claim that usos y costumbres reflect the actual practices of generations of Cochabambans. But the concept also signifies a connection with Andean custom, cultural autonomy, and independence from state intervention in communal governance. The disruption of usos y costumbres has, for many Cochabambans, come to mean the disruption of both a contemporary way of life and perceived long-held cultural practice.

Even for those Cochabambans who do not practice irrigation, usos $\mathrm{y}$ costumbres have become an idealized element of regional identity-a central piece of what it means to be Cochabamban. In urban areas they can be a way of preserving a connection to "Andean ancestry." ${ }^{60}$ Perceptions of rural practices have become almost synecdochic for both the regional and the national. Throughout the region usos y costumbres can operate discursively to refer to ethnic heritage, ideals of local governance, attachments to region and land, or a connection to the past. ${ }^{61}$ These meanings are continually contested as usos y costumbres are intentionally invoked to do particular political work at the regional and national level, while also serving to organize the comings and goings of daily life. Usos y costumbres have become a thing to which irrigators, other campesinos, urban, and peri-urban Cochabambans refer, working to create commonalities in the valley and serving as a piece of Cochabamban culture worthy of reification and protection.

Conceptions of a shared connection with Andean heritage worked throughout the water wars to summon groups both into being and onto the streets. ${ }^{62}$ Imagined connections were brought to the fore through ideas of shared cultural heritage surrounding water. Movement organizers and participants projected a coherence to what it meant to be

59 Perreault 2008.

${ }^{60}$ Kosek 2006 notes a similar phenomenon in his analysis of Truchas, New Mexico.

${ }^{61}$ Anthropologists Jean and John Comaroff capture the coming together of past and present nicely with their definition of heritage. "Heritage," they argue, "is culture named and projected into the past, and, simultaneously the past congealed into culture. It is identity in tractable, alienable form, identity whose found objects and objectifications may be consumed by others and therefore delivered to the market." Comaroff and Comaroff 2009,10. These comments shed light on the ways in which heritage can work to mobilize identities for political protest.

${ }^{62}$ See Bourdieu and Thompson 1991, Brubaker 2004, Butler 1997, and Wedeen 2008 for discussions of this performative aspect of identity mobilization. 
both Andean and Cochabamban and to the role that water played (and should play) in constituting regional and ethnic identifications. The privatization contract was an affront to the past, present, and future- to a shared heritage that was "authentically" Cochabamban. One participant in the November blockade reflected, "[T] hey were taking away our rituals, our way of relating to the water, of managing it. It was our lives we were defending." ${ }^{63}$ Water evoked, at once, attachments to imagined and quotidian communities representing perceived ties to a past, a way of life in the present, a neighborhood, a region, and an ethnic group. Community belongings that could have been in tension with one another appeared to exist seamlessly when water was at stake.

\section{Growing Urban Participation: The Civic Committee and JUNTAS VECINALES}

The coalition in opposition to the Aguas del Tunari contract continued to grow throughout 1999 largely through increased urban participation. On November 1, Aguas del Tunari officially replaced SEMAPA, and on November 4, Cochabamban regantes led a second blockade, this time on a larger scale and with increased participation from urban and rural groups. The regantes were joined not only by CODAEP, but also by the Cochabamban Civic Committee and local juntas vecinales (neighborhood councils). ${ }^{64}$ FEDECOR's Fernández called the urban-rural alliance "a peculiar characteristic" 65 of the November blockades, alluding to the unique nature of the collaboration and recalling the divisions that had surfaced so clearly only a few years earlier during conflicts over proposed wells in peri-urban areas. The coalition successfully blocked the highway linking Cochabamba to Santa Cruz and Sucre (the second major artery that passes through Cochabamba), as well as the CochabambaOruro-La Paz connection. The participation of the civic committee and the juntas vecinales demonstrated the broad urban resistance to Aguas del Tunari's arrival. ${ }^{66}$

The early participation of the juntas vecinales draws attention to

${ }_{63}$ Author interview with blockade participant, February 8, 2010. Some of the interviews were conducted in confidence and the names of the interviewees are withheld by mutual agreement

${ }^{64}$ Juntas vecinales gained political power and prominence as a result of the 1994 Law of Popular Participation. They are often called organizaciones territoriales de base in rural areas. Civic committees emerged throughout Bolivia in the 1950s and 1960s to articulate and represent regional interests. While not officially tied to the government, they achieved local recognition as legitimate representatives of civic interests and were often included in government plans and negotiations.

${ }_{65}$ Peredo, Flores, and Fernández 2004, 126.

${ }^{66}$ Leadership of both organizations initially voiced support for the contract. It was not until organizing was well under way that they joined the protest movement. 
SEMAPA's shortcomings and how those shortcomings worked to produce conceptions of local community. SEMAPA's water networks did not reach a substantial proportion of Cochabamba's residents. In 1999, only 64 percent of the city's population had access to a SEMAPA connection in their homes, ${ }^{67}$ the majority of whom were in the city's northeast and central zones. Much of the south and the northwest were left unconnected. Furthermore, SEMAPA appeared to be in no hurry to reach them. At the time of the concession, SEMAPA had gone nine years without any network expansions. As a result, many inhabitants - rich and poordeveloped alternative ways to access water. The experience of developing, maintaining, and pursuing these alternatives fundamentally shaped local relationships with water, imbuing this subsistence good with community-related meanings tied to survival, dignity, and independence.

Many poorer communities relied on a combination of local water vendors who visited communities with aguateros (water trucks) to fill private cisterns and communally constructed and managed wells. These alternatives became the core of local community relationships, shaping daily life through the efforts to obtain water and communal governance through efforts to manage it. President of Barrio Petrolero's (located in the southern part of Cochabamba city) junta vecinal Raúl Aguilar argued that "It was the obligation of the state to provide affordable water. They didn't, so we made our own wells. Then [with the arrival of Aguas del Tunari] they were going to take away these wells. With them we would lose our dignity, our community." 68

The water cooperatives that developed and managed communal wells offer an excellent example of the ways in which water helped to construct, and in turn, symbolize community for many of Cochabamba's poorest. ${ }^{69}$ While each cooperative functioned differently, most operated under similar general principles. Residents of a given community contributed time and money to establish, maintain, and govern a communal system of water collection and distribution. The water came either from a communally constructed well or from a communally managed connection to SEMAPA, where the cooperative bought water in bulk from the municipal agency and then managed its distribution. In exchange, coop members could access water at appointed times or in predetermined amounts. Most cooperatives had a system of punishment in place, usually a schedule of fines, for those who violated the communally agreed-upon rules for water collection and management.

${ }^{67}$ Laurie and Marvin 1999, 1405.

${ }_{68}$ Author interview with Raúl Aguilar, January 28, 2010.

${ }_{69}$ The cooperatives recall the Ostrom 1990 work on common pool resources. 
The cooperatives served as a source of pride for the communities that developed them. The cooperatives reflected hard work, commitment, and entrepreneurship, and water took on these meanings. It became a symbol of the power of communal cooperation intimately tied to ideals of communal governance and neighborly relations.

Southern zone resident Carlos Oropeza echoed the sentiments of other southern zone interviewees when he said, "Thanks to water we are organized ... we have dignity. Water gets us to work together.... The contract would have taken that away so we all participated." ${ }^{70}$ The Aguas del Tunari contract threatened the hard-won structures of local governance and reciprocity.

Another resident commented, "Water dignifies people. Water brings us together. It gets us to work together. There aren't political divisions with water. It doesn't have a political color. It brings everyone together." 71

Of course, water does not always work this way. Communal governance structures are not the product of, nor do they continually produce, a constant state of collaboration and harmony. Meetings are contentious, and members do not always believe that others are doing their fair share, that the fees are appropriate, or that the water is being well managed. Yet, the experience of struggle is shared. In the Cochabamba case, the threat from outside - the national government and the private company-highlighted the shared struggle and allowed common experiences and common perceptions that community was at stake to dominate discourse. Microlevel understandings of the ways in which water and community were intertwined coalesced at the mesolevel.

SEMAPA's failings created a sense of shared suffering, even if the degree and type varied greatly, which extended to Cochabambans of all classes, even those with water connections. Prior to the concession, the water authority was synonymous with poor quality and coverage. Furthermore, water provision through SEMAPA was insufficient to meet demand. In 1999 SEMAPA provided only 70 percent of the water demanded by the region's residents and businesses, ${ }^{72}$ and only 23 percent of the connected population received water for a full twenty-four hours a day. ${ }^{73}$ Many wealthy residents boasted not only SEMAPA connections, but also private wells. One resident of Cochabamba's wealthier northern zone commented, "Have faith in SEMAPA? I don't think so. We knew

\footnotetext{
70 Author interview with Carlos Oropeza, February 10, 2010.

71 Author interview with Cochabamba resident, February 9, 2010.

72 Figure calculated from Laurie and Marvin 1999, 1405.

73 Crespo Flores 2003, 114.
} 
we needed our own water so we built a well. We could usually rely on the well, but things would have been easier without it." ${ }^{74}$ Whether rich or poor, Cochabambans had been left on their own to ensure daily access to water for their families and their businesses. ${ }^{75}$

SEMAPA's shortcomings also worked to produce broadly shared regional language through large-scale efforts to overcome the valley's water shortages. After years of fighting and waiting for the construction of the Misicuni project, which was to bring water to the valley through a thirty-meter tunnel, the dream was dead. With Aguas del Tunari at the helm, Misicuni-the project that had been touted as the region's savior, taking on a mythical status as the vehicle through which Cochabamba would be reborn - would never come to be. ${ }^{76}$

The failings of SEMAPA's services bound many Cochabambans together. Ties included the intimate connections of quotidian communities that arose around neighborhood-level struggles to access water, and the mediated relationships that emerged through the shared knowledge that Cochabambans throughout the region's urban and peri-urban areas faced similar daily challenges as they sought access to reliable, affordable water. The understandings of water produced through these two processes overlapped in some places and were distinct in others. But however distinct or contradictory they may have been, they fit into the larger political project of opposition to the Aguas del Tunari contract without conflict. An external threat - the private company and the national government - highlighted the shared struggle and allowed common experiences and common perceptions that community was at stake to dominate discourse. Microlevel understandings of the ways in which water and community were intertwined coalesced at the mesolevel.

\footnotetext{
${ }_{74}$ Author interview with Cochabamba resident, February 9, 2010.

75 One might expect that, particularly for middle- and upper-class Cochabambans, these state failures would easily translate into expressed desires for market intervention. For some it did. "We needed to try something new," one resident of Cochabamba's north commented (author interview, Cochabamba, February 9, 2010). "SEMAPA was corrupt. It didn't work. It wasn't going to work. We lost an opportunity, you know? A chance to begin again. Privatization is not always bad. But the Cochabamban people thought they were losing something, that the government was taking something that was ours away and giving it to rich private corporations." While his comments are colored by failures of water services in the post-water war era in Cochabamba, they reflect the sentiments of Cochabambans who hoped that a private company could solve the region's water problems. This interviewee did not join the protesters in 2000 , but his language offers insights into why potentially like-minded Cochabambans did support the water wars. Something that was perceived as shared was passing into the hands of outsiders who could not know what was at stake in the principles and practices of local water relationships.

${ }^{76}$ For a discussion of Misicuni's mythical status in Cochabamba see Crespo Flores 2003; Laurie and Marvin 1999.
} 


\section{The Coordinadora and the First Water War}

In the wake of the Vinto blockades, movement leaders met on November 12, 1999, to discuss next steps. That evening, those in attendance founded the Coordinator for the Defense of Water and Life (Coordinadora por la Defensa del Agua y de la Vida [Coordinadora]). The Coordinadora brought together strong preexisting organizations to work in common cause and served as the center of the movement through the final April protests. FEDECOR and CODAEP joined with the Departmental Workers' Union (Central Obrera Departamental, COD), the Federation of Manufacturing Workers of Cochabamba (Federación de Trabajadores Fabriles de Cochabamba [Fabriles]), the teachers' union, the transportation workers' union, the peasant union, and others. The alliance spanned not only urban-rural divides, but also social and class boundaries. ${ }^{77}$ Water's historical and contemporary roles in the region combined, allowing relationships with water to be perceived as shared by groups as disparate as regantes, factory workers, and business owners.

Participation in an "Assembly of the Cochabambinidad" by the civic committee on December 20 reveals not just cross-sector, but also cross-class opposition to the contract. A photograph that appeared in the local newspaper Opinión, showed "businessmen, authorities, and leaders" at the meeting, and the accompanying article quotes the "representative of private business to the civic committee," Carlos Olmedo, as saying "[W]e have to adopt protest tactics to defend the interest of the Cochabambans." ${ }^{79}$ Two days later approximately fifty organizations participated in a march to the center of Cochabamba, where they called for a renegotiation of the Aguas del Tunari contract and Law 2029. ${ }^{80}$

The participation of the transport union was particularly notable. Opinion reported that the transportation union's participation came after nineteen years of silence. Maclovio Zapata, the union's leader, said it hadn't joined previous marches addressing other economic reforms "because there were misunderstandings with the other labor organizations; but now the problem affects all Cochabambans." ${ }^{81}$

77 Notably, neither civic committee nor the Federation of Neighborhood Organizations (Federación de Juntas Vecinales, FEJUVE) leadership attended the November 12 meeting; even while their membership participated in Coordinadora-convoked marches, the leadership of both organizations distanced themselves from the Coordinadora's activities.

78 The word invokes Cochabamban-ness, implying a strong attachment to being Cochabamban.

79 "Cochabamba en emergencia exige rebaja de tarifas de agua," Opinión, December 21, 1999.

80 "Cochabambinos protestarán hoy contra subida de precios," Presencia, December 22, 1999.

81 “Cochabamba unida, rechaza reajuste de tarifas de agua," Opinión, December 23, 1999. 
In spite of shared grievances in the past, Cochabamban unions had been unable to unite to fight for shared interests. The education, factory, and transportation unions, for example, had each fought on their own for individual goals, often antagonizing each other in the process. The threat to water created a perception of shared destiny; each may have perceived different communities to be at risk, but water provided a common language.

When Cochabambans saw their first water rate hikes in early January 2000, perceptions of unity manifested themselves in calls for large-scale protest. $^{82}$ In seven months, a movement that began with a small group of professionals had grown to include unions, neighborhood associations, and even previously unorganized Cochabambans. The appeal to defend water made the Coordinadora "at once rural and urban, multiclass and multiethnic, straddling what have historically been often been fractious divides." ${ }^{3}$

Ultimately, the water concession contract simultaneously threatened perceived material interests and indexed some combination of nation, region, ethnicity, heritage, and local community. These symbols brought Cochabamba's disparate groups together, apparently united in a single cause. I do not seek to undervalue the importance of the material claim. In fact, many interviewees cited the rate increase as the "detonante" (detonator) for the large-scale protests in January 2000. Yet, while the rate increase mattered-I do not expect that there would have been large-scale mobilization without it-there was something more at work. In the days that followed, those who could afford the rate hikes, as well as those who were not connected to the municipal water system, were holding banners in the streets and invoking a violation of usos y costumbres. As the president of Barrio Petrolero Aguilar put it, the reform "affected everyone, it did not matter what salary or sector." ${ }^{4}$

Cochabambans had been mobilizing around water for decadesthey had mobilized in individual neighborhoods to demand improved SEMAPA services, to advocate for the Misicuni project, to form an irrigators' union when a new water law threatened irrigators' interests,

82 In some cases, hikes were as high as 200 percent (Shultz 2003; Peredo 2003; García, García, and Quintón 2003), though average increases appear to have hovered closer to 60 percent. For those Cochabambans paying the lowest possible rate for their water, the average cost of water went from 7 percent to 11 percent of the minimum monthly wage ( 355 bolivianos or US $\$ 60.01 / \mathrm{month}$ ). For the approximately 55 percent of the Cochabambans living below the poverty line (Bs293/month or US $\$ 41$ ), the minimum monthly payment would have exceeded 35 percent of income, not including additional meter fees. Instituto Naciónal de Estadísticas 2006.

${ }_{83}$ Albro 2005, 251.

${ }^{84}$ Author interview with Raúl Aguilar, January 28, 2010. 
and to fight for and to stop new wells in peri-urban areas in the 1990s. The water wars were unique because the groups that mobilized, many of which were organized around sector, class, or neighborhood-specific claims, found a common cause without challenging the particularities of the understandings of water that emerged through multiple contextdependent relationships. Water-related demands on the state varieddifferent individuals and group members had different perceptions of priorities and interests when it came to making claims. Solutions to problems of scarcity, corruption, and poor service could vary depending on differences in water-related practices. Disparate understandings made unity difficult when it came to advocating for changes in state policy. Yet opposition to Aguas del Tunari was based in multiple meaning-making practices and understandings of water. With the Aguas del Tunari contract, those interests and understandings, if only for the months of the mobilization, overlapped.

On January 11, 2000, the blockade for dignity began. For three days, irrigators' associations effectively blocked strategic roads, and neighborhood associations on the periphery set up barricades. The civic committee and the Coordinadora rallied thousands of Cochabambans to the streets. Regantes, factory workers, architects, engineers, environmentalists, students, transportation workers, teachers, neighborhood organizations, and local water committee members all participated. Anecdotes describe children creating roadblocks with bicycles and sticks, elderly women lying across the streets, and bank employees offering aid to protesters. ${ }^{85}$ José Antonio Gil, the commander of the army unit stationed in Cochabamba, recalls, "My wife, my child, my household employee - they were all in the streets." ${ }^{\prime 6}$ The protests shut down the regional airport as well as the two major highways into and out of the city. ${ }^{87}$ City officials called in hundreds of police officers to control the march to the central plaza; they attempted to reopen the roads, but protesters stayed put.

The significance of water to the livelihoods and identities of $\mathrm{Co}^{-}$ chabambans allowed the Coordinadora to explicitly call on Bolivian and Cochabamban identifications, underscoring collective vulnerability without trying to distinguish the needs or interests of distinct groups within a broad framework of citizenship. Maria Esther Udaeta, who in February helped to negotiate agreements with the government, recalls that she felt as though to threaten water "was to violate our

85 Olivera 2004; Shultz 2003.

${ }^{86}$ Interview with José Antonio Gil, February 8, 2010.

${ }^{87}$ Shultz 2003. 
sovereignty." ${ }^{88}$ It is a comment that resonates with individual, neighborhood, regional, and national-level conceptions of self-determination. Cochabambans marched behind the Bolivian flag, and images of it held in the air dot photos of the protests. For Aguilar, protesters took the plaza "in the name of Bolivia. . . The state forfeits the flag when they don't do their job. The people raised the flag because they were defending the country." ${ }^{89}$ The highly regional Misicuni myth also took center stage. Placards held by protest participants read, "No to the rate increase [tarifazo], yes to Misicuni." The Aguas del Tunari contract was perceived as the end to the promise of Misicuni-the modernization that Misicuni was to bring and the past it was to recall were both somehow made impossible. Regional and national imaginaries did not appear to be in competition with one another.

But even as Cochabambans invoked national patrimony and promises of regional "progress," they also deployed decidedly ethnic symbols. The indigenous wiphala, a flag often used to represent a broadly Andean indigenous category, also filled the protests. The perceived threat to water tapped into national and ethnic identifications.

COD leader Walter Antezana's recollections echo those of other participants. Both the Bolivian flag and the wiphala, he recalls, "brought more energy to the streets. They reminded us what was at stake, what we were fighting for." ${ }^{\prime 0}$ For many participants, the wiphala appears to have simultaneously symbolized usos y costumbres and conceptions of regional heritage. One participant who was in his early thirties at the time of the protests said, "The wiphala was about respect; respect for our past, respect for who we are, for our beliefs and customs." ${ }^{11}$ To defend water was to defend cultural practice, the region, and the country. Ethnic, nationalist, and regional imaginings came together without conflict. Water had tapped into powerful imagined communities that were, at that moment, able to bring people to the streets and to exist together apparently seamlessly.

The kind of plural nationalism that emerged during the January protests was available to organizers because the conception of water as national or regional patrimony resonated simultaneously with national political and indigenous claims. Furthermore, the claims did not compete with each other. ${ }^{92}$ Indeed, many interviewees who did not identify as Aymara or Quechua claimed that their heritage was at stake as

${ }^{88}$ Author interview with Maria Esther Udaeta, January 31, 2010.

${ }^{89}$ Author interview with Raúl Aguilar, January 28, 2010.

${ }_{90}$ Author interview with Walter Antezana, September 9, 2008.

${ }_{91}$ Author interview with water war protester, August 25, 2008.

${ }^{92}$ In some cases, as I am arguing here, national patrimony may overlap with indigenous patrimony. Others may consider their national and indigenous roots as highly distinct-they are Quechua and 
well. One participant in the water wars who as a college student in her mid-20s at the time and did not identify as indigenous, said, "Usos y costumbres can't be lost. They are an important part of where we come from." ${ }^{3}$ Union leader Antezana claimed that part of what was at stake was "lo andino [the Andean]." Water could be described as a particular right of Cochabambans, as belonging to Bolivians, or as a reflection of perceived Andean or regional customs. In the water wars participants could make each of these claims in the same utterance without challenging perceptions of meaning coherence.

This potential for simultaneous imaginings served to unite not only a variety of sectors and regions, but also a variety of income levels. When questioned, every interviewee who had been present at the events in January 2000 recalled that participation was not correlated with class. Instead, a language of solidarity grounded in region and country permeated my interviews and informal conversations. Furthermore, notions of class need to be understood in relational terms. Even those who may have been from a financially privileged class in the Cochabamban context may have also considered themselves to be part of a class that had been ignored or marginalized by national elites. These shared perceptions of marginalization tapped into the imagined communities of nation and region, and motivated Cochabamba's wealthy to participate.

Quotidian communities also brought people to the streets. Explanations of the water wars simply as a reaction to increased water rates are equally confounded by the participation of those who were not paying municipal water bills as by the participation of their wealthy neighbors. As these individuals did not have hookups to the SEMAPA network, none of them was contending with the water-rate increase. They did, however, have to contend with fears that the Aguas del Tunari contract would violate their hard-won perceptions of autonomy. The contract allowed the company to place meters on community-constructed wells and water networks. These meters would not only measure usage and calculate charges for systems that had been privately developed, they could also potentially disrupt the quotidian community structures developed for regulating, maintaining, and charging for water services. While many of the protest participants who did not receive water bills referenced national, regional, or ethnic claims when explaining their actions, they uniformly emphasized the perceived violation of the small communities that they had developed to facilitate access to water.

Bolivian-and do not consider the two identities as overlapping. Robert Albro 2005 suggests that the water wars brought indigenous and Bolivian conceptions of nation together under the banner of "popular 'citizenship."”

93 Author interview with water war protester, August 25, 2008.

94 Author interview with Walter Antezana, September 9, 2008. 
Placards held by demonstrators during the protests in February indicate how some participants perceived the Aguas del Tunari contract as a threat to local community autonomy and organization. Footage of the events shows handwritten signs reading, "Long live the self-organization of the pueblo [people/town/community]," "The pueblo organizes alone and without parties," and "Popular support can more than any state." 95 All three statements are indicative of the perceived divide between the people and the state. But they also reveal the local connection of water to self-determination. References to self-organizing and the effectiveness of popular action without the state speak to pride in the very protests themselves and in Cochabambans' history of providing for themselves where water was concerned. The events of the water wars exemplify the self-reliance invoked by these phrases. But the statements also speak to the perception of the Aguas del Tunari contract as a threat to the local, community-based organizational efforts that dominated relationships with water in urban and rural areas throughout the valley.

The January protests lasted three days. Government representatives and movement leaders sat down to negotiate and people left the streets, but the water wars had undoubtedly begun. The disparate identifications and interests of protesters coalesced into what the scholar Rocío Bustamante calls "a single group in the streets," ${ }^{6}$ difficult to isolate, divide, or undermine. Why Cochabamba erupted when and how it did can only be explained when specific attention is paid to the mobilizing power of the meanings with which water was imbued. Cochabambans took to the streets because local communities and regional, national, and ethnic identifications were perceived to be at risk. Material relationships with water mattered, but it is important to also understand how those material relationships worked to produce communal understandings, ideas, and attachments. Cochabambans took to the streets again in February and April, and other dynamics took hold as the movement grew. Yet the ways in which water indexed community explains why a broad coalition was initially possible.

\section{Engaging Alternatives}

The Cochabamba case is particularly well-suited to exploring the dynamics of social movement emergence because of the lack of variation in

95 Rioja Vasquez 2002. In Spanish, the signs read: "Viva la autoorganizacion del pueblo," "El Pueblo organiza sólo y sin partidos," and "La resbaldia popular puede mas que cualquier estado."

${ }_{96}$ Bustamante, Peredo, and Udaeta 2005, 80. 
other elements often central to theorizing on social mobilization. Mobilizing structures, political opportunities, and frames all undoubtedly played a role at various stages in the water wars and provide an important foundation to understanding the dynamics at work. ${ }^{97}$ Most notably, Cochabamba was home to a number of mobilizing structures-unions and neighborhood organizations in particular-that proved critical to the emergence of resistance in the region. Furthermore, the region is known as one of Bolivia's most contentious; Cochabamba's peasants played an important role in agitating for agrarian reform in the years following the 1952 revolution, and they spearheaded resistance to the economic adjustment Hugo Banzer adopted during his dictatorship in $1974 .{ }^{98}$ Yet neither the dynamics of the movement's emergence nor its plural composition can be explained by looking at resources alone. Associational resources available to local organizers varied little in the late 1990s, and in spite of a variety of grievances, large-scale, widespread protest did not emerge until the privatization of water. Furthermore, in spite of similar organizational networks and significant material hardship, broad-based protest over a variety of related claims did not emerge in the rest of the country until after Cochabambans had been in the streets for more than three months.

Similarly, changes in political context cannot entirely explain the events in Cochabamba. Local changes in the political opportunities available to social movement organizers in the spring of 1999-prior to any significant mobilization-do not appear to be unique to the water movement, and national changes in political opportunities were not unique to Cochabamba. Attention to this dynamic cannot explain the mechanisms that brought a diverse group of Cochabambans to the streets in the movement's early months.

Collective action frames were undoubtedly critical to the movement's emergence and its ability to attract so many Cochabambans. ${ }^{99}$ The threat to water resonated with Bolivian, Cochabamban, and indigenous nationalist master frames, allowing the issue to appeal even to those not severely affected by the rise in water rates. This article

${ }^{97}$ See McAdam, McCarthy, and Zald 1996; McAdam 1999; Tarrow 1998; McAdam, Tarrow, and Tilly 2001; Aminzade 2001; Goodwin and Jasper 2004 for overviews of dominant approaches to social movements as well as critiques of those approaches.

${ }_{98}$ The protests resulted in what has come to be called the Masacre del Valle (massacre of the valley).

${ }^{99}$ I use the term "frame" in the way it is generally deployed in social movement scholarship. See, for example, Snow and Benford 1988, 137, who describe a frame as an "interpretive schema that simplifies and condenses the 'world out there' by selectively punctuating and encoding objects, situations, events, experiences, and sequences of action." Framing refers to "the process of defining what is going on in a situation in order to encourage protest" (Noakes and Johnston 2005, 2). While these usages draw on Goffman 1974, they imply a far narrower conceptualization of the term. 
helps us to understand why these frames were available to this particular movement at this particular moment.

I argue that the agency of social movement entrepreneurs should be understood as being in constant interaction with cultures that are produced through iterative, dynamic, meaning-making processes. Within the social movement literature, framing is often something that is "being done." 100 It is active, signifying work that can generate, reproduce, and challenge dominant meanings. ${ }^{101}$ Social movement entrepreneurs actively create and maintain meanings for participants and nonparticipants throughout the movement process. Yet these entrepreneurs often build on preexisting interpretive frames. Collective action frames can be "the outcome of negotiating shared meaning," 102 but the negotiations will be more successful if the interpretive schema from which they are developed overlap; interpretive processes are at work well before savvy social-movement entrepreneurs engage in their own processes of meaning construction. Indeed, while movement organizers in Cochabamba deftly deployed frames that had the "empirical credibility, experimental commensurability, and ideational centrality or narrative fidelity"103 necessary to resonate with Cochabambans, the question remains as to why they were able to develop frames with these characteristics. ${ }^{104}$ Why was the water movement able to create and capitalize on resonant master frames? Why did nationalist, ethnic, and regional frames appeal so powerfully when water was at stake? Here, we must look to the meaning-making processes that were taking place before the mobilization. Frames mattered, but to understand how and why they worked the way they did, the microlevel processes through which Cochabambans made sense of what was at stake in the Aguas del Turnari contract must be explored. ${ }^{105}$

\section{CONCLUSION}

Three potential avenues for further research and theoretical work emerge from the Cochabamba case. Most broadly, the analysis indicates that

100 Benford and Snow 2000.

101 Benford and Snow 2000.

102 Gamson 1992, 111.

${ }^{103}$ Snow and Benford 1992, 140.

104 By empirical credibility, the authors refer to the "apparent evidential basis for a master frame's diagnostic claims" (Snow and Benford 1992,140). Experiential commensurability suggests direct experience with a problem, and ideational centrality refers to how well the frame "rings true" with a given contextual system.

${ }^{105}$ I also explored threshold and demonstration effects, prior history of mobilization, and charismatic leadership as potential explanations. None offered satisfactory accounts of the events. Space constraints limit their inclusion here. 
paying attention to what people perceive to be at stake in marketization processes matters for the dynamics of contention. When we understand claims as more than a material set of things, we can better explain how and why apparently similar market reforms in different contexts might work differently to produce political resistance. ${ }^{106}$ More specifically, the ways in which water indexed community in Cochabamba suggests that broader theorizing on the intersection of water and contention is warranted. There might be systematic ways to understand when marketdriven threats to water would work to produce mobilized resistance and when they would not. Assuming that there are strong mobilizing structures on which a movement can draw and that movement leaders understand political opportunities to be open, ${ }^{107}$ we might expect marketization of water to produce broad-based contention in places where water-related practices help to construct conceptions of communities in urban and rural areas. Areas where clean water does not simply arrive at people's homes on demand through a tap but requires daily effort might be particularly likely places for water to take on community-related meanings. This kind of "artisanal" 108 relationship with water is likely to put it at the center of life and livelihood and, as a result, of community. The events in Cochabamba indicate that broader theorizing is possible on when and where water indexes community.

Furthermore, the research pushes us to think systematically about resources other than water that might have similar political effects. Are there categories of goods that are likely to symbolize community and generate comparable episodes of contention when markets threaten to interfere? The mechanisms explored in this article suggest that any good at the center of daily life and livelihood could come to symbolize community. The daily practices that emerged around water in $\mathrm{Co}_{-}$ chabamba are rooted in its crucial role in historical and contemporary subsistence. ${ }^{109}$ Water's role in material life makes it central to daily practices and cultural imaginings. With these mechanisms in mind it becomes possible to imagine that any subsistence resource at the center of routine, communal, and material practices might come to symbolize neighborhoods, regions, nations, or ethnic groups in the way that water did in Cochabamba.

While this discussion clearly calls for further comparative research, literatures on moral economies and contention ${ }^{110}$ suggest that we can

106 See Simmons 2014.

${ }_{107}$ I do not mean to reproduce the vagaries and ambiguities of the political opportunity concept here. I acknowledge that the concept is poorly defined. See Goodwin and Hasper 2004.

108 Bakker 2003.

109 See Simmons 2014.

110 For example, Thompson 1971; Scott 1976. 
think broadly about connections between material livelihood, markets, and social mobilization. ${ }^{111}$ When people perceive a subsistence good to be at risk, material and symbolic worlds are at stake; citizens take to the streets to defend not only their pocketbooks, but also their conceptions of community. We should expect these kinds of threats to be particularly likely to produce mobilized resistance.

\section{APPENDIX 1 \\ Ethnographic and Historical Research Methods}

While in the field, I participated in Cochabamban life by taking part in social gatherings, political events and protests, and office activities. I observed formal meetings and workshop sessions, read local newspapers, went to plays, concerts, and movies, and watched local television. I spent time speaking about water with local residents and observing local practices involving water governance, management, use, and collection. These experiences gave me the tools to make sense of particular actions or words in the context in which they took place or were deployed.

I conducted over 100 formal, open-ended, and semistructured interviews with Cochabambans, many of whom participated in the water wars directly and some of whom did not. I interviewed leaders of most of the major organizations involved, including local unions and neighborhood groups. I was able to meet, often more than once, with leaders from over twenty local organizations whom I identified through newspaper coverage of the events, internal movement documents collected during archival research, or recommendations from other interviewees. I also conducted interviews with Cochabambans who were not movement leaders but were living in Cochabamba at the time of the water wars. Some of these individuals were identified in the course of my conversations with movement leaders. Most, however, came through informal conversations during public events, at local grocery stores, marketplaces, or cafes or other venues throughout the city. At each of these venues I would approach individuals I did not know, ask them if they were living in Cochabamba during the water wars, and whether they

111 In spite of the emphasis on moral economies, Thompson and Scott remain focused on the material qualities of subsistence. The general references to necessities and food beg disaggregation, as not all food is likely to be encompassed by a subsistence ethic. In particular, Scott's focus on the nourishment that subsistence goods provide overlooks the ways in which the material and the symbolic work to constitute each other when subsistence is at stake. Neither author takes up the ways in which subsistence goods might symbolize neighborhood, nation, region, ethnicity, etc. Yet even if these authors' emphasis on subsistence appears confined to a commitment to the material, it does indicate that such threats may play a systematic role in social mobilization. 
would be willing to speak with me about their experiences. I identified event participants and nonparticipants for interviews in this manner.

Historical research included analysis of written materials (for example, newspapers, pamphlets, movement documents, and scholarly works); recorded speeches; and films produced during and prior to the mobilizations. I read all of the coverage of the water privatization process and the water wars in two national newspapers, Presencia and $L a$ Razon, and two Cochabamba papers, Opinión and Los Tiempos. I read Cochabamba print media (including Opinión and Los Tiempos) from the two decades prior to the water waters looking for water-related coverage specifically. My observations of lived experiences in 2008 and 2010 helped me to interpret these earlier texts, to understand the work that particular words or phrases may have been doing in movement slogans, or the ways in which particular symbols worked to generate unity on the streets.

That I was not in Cochabamba before and during the events of the water wars posed particular challenges. The protests unsettled water's meanings in the region and each new phase of the mobilization produced new languages, conceptions, and relationships. I therefore relied heavily on documents produced, utterances made, and images deployed during or before the protest events. Newspaper accounts, film footage (including a number of documentaries produced in Bolivia prior to the protests), scholarly works, and other written texts proved particularly useful. For analysis of the movement, I relied heavily on media coverage and film footage produced at the time. While in some cases I used these sources to understand who was at a particular meeting or when it happened, most often I used the texts in an interpretive fashion. I analyzed the words or images deployed and tried to understand the work those words or images were doing in the context in which they were used. Knowing what a placard said, who held it, and what they were doing when they did, allowed me to interpret what it meant in that particular context.

Many of the practices around water access in Cochabamba, including how it was managed and distributed, changed little from the prewater war days to the time of my field work - a span of about eight years. As a consequence, I was able to supplement material produced prior to the water wars with interviews and participant observation. For example, I was able to attend meetings of water governance councils where they discussed the same kinds of routine challenges and daily operations that they might have encountered eight to ten years prior.

I employed three strategies to address additional inferential chal- 
lenges. First, I looked to the work performed by discourses, both those that emerged during the movement itself and those of actors as they recalled the events, to make the movements intelligible. In fact, whether a source "misremembered" is largely unimportant to the interpretive component of the analysis conducted here. How sources remember their experiences sheds light on what those experiences meant and the work they do in the source's understanding of the world. These are far more important than the facts of what may or may not have happened on a given day. Second, when attempting to piece together a sequence of events or actions, I strove to determine the credibility of sources by thinking about any incentives they might have had to lie intentionally. For government officials and movement leaders, as opposed to participants, this was particularly interesting. Their responses often ran counter to what I might have expected had the actors intended to misrepresent or knowingly alter accounts of events. In such cases, I found answers particularly credible. Third, when I did rely on newspapers and interviews to reconstruct a sequence of events, I made sure to corroborate facts from accounts in more than once source. Most notably, whether the statements of interviewees are true is often less important than what they signal about dynamics of the protest movements and the subjects' relationship with water. 


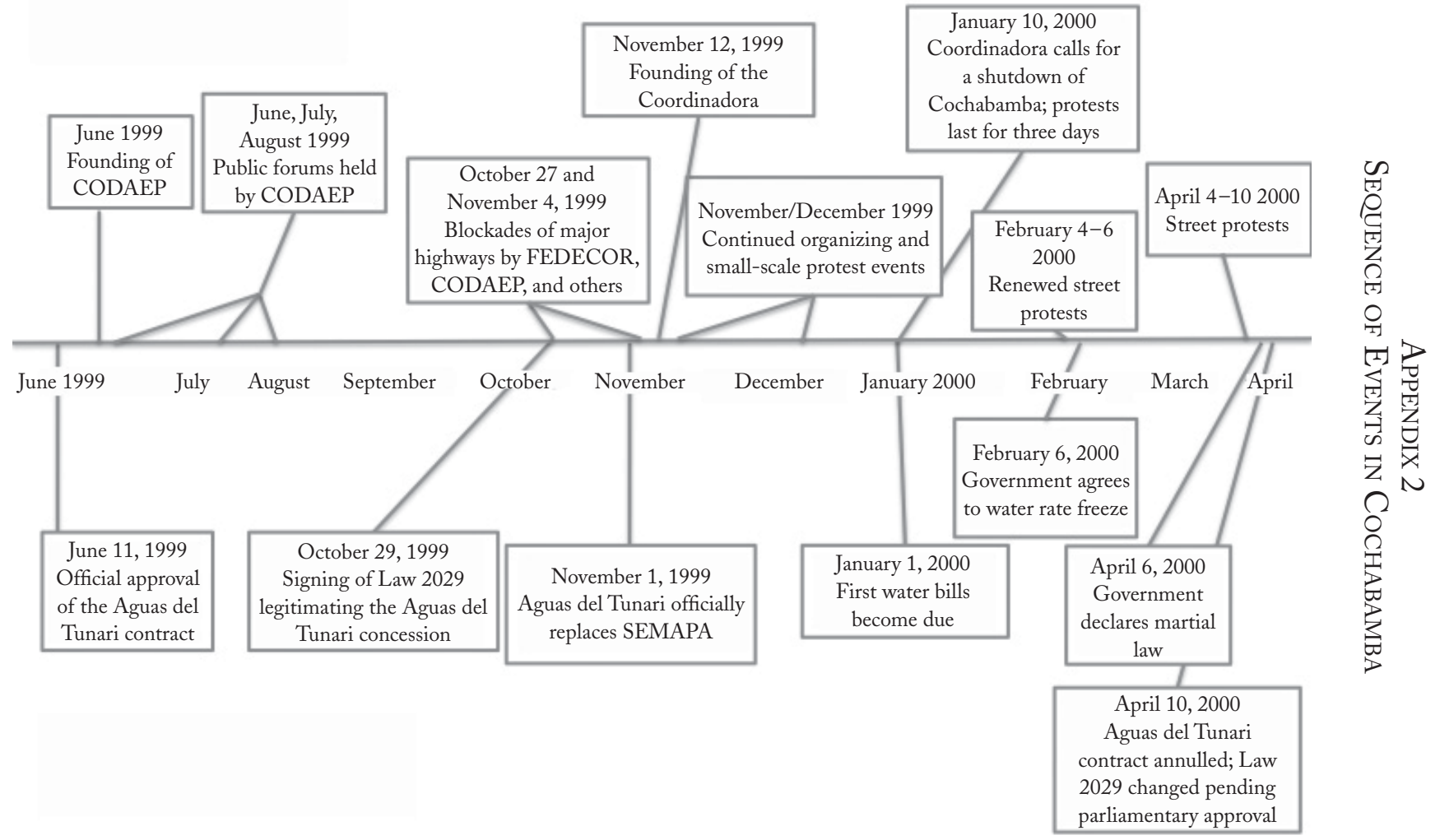




\section{REFERENCES}

Agüero, Felipe, and Jeffrey Stark, eds. 1998. Fault Lines of Democracy in PostTransition Latin America. Coral Gables, Fla.: North-South Center Press/University of Miami. Distributed by Lynne Rienner Publishers.

Albro, Robert. 2005. "The Water is Ours, Carajo! Deep Citizenship in Bolivia's Water War." In June Nash, ed., Social Movements: An Anthropological Reader. Malden, Mass.: Blackwell Publishing.

Aminzade, Ronald. 2001. Silence and Voice in the Study of Contentious Politics. Cambridge, UK: Cambridge University Press.

Anderson, Benedict R. O'G. 1991. Imagined Communities: Reflections on the Origin and Spread of Nationalism, rev. and extended ed. London, UK: Verso.

Arce, Moises, and Paul T. Bellinger, Jr. 2007. "Low Intensity Democracy Revisited: The Effects of Economic Liberalization on Political Activity in Latin America." World Politics 60, no. 1 (October): 97-121.

Assies, Willem. 2003. "David versus Goliath in Cochabamba: Water Rights, Neoliberalism and the Revival of Social Protest in Bolivia." Latin American Perspectives 30, no. 3 (May): 14-36.

Auyero, Javier. 2007. Routine Politics and Violence in Argentina: The Gray Zone of State Power. Cambridge, UK: Cambridge University Press.

Bakker, Karen J. 2003. An Uncooperative Commodity: Privatizing Water in England and Wales. Oxford, UK: Oxford University Press.

Benford, Robert, and David Snow. 2000. "Framing Processes and Social Movements: An Overview and Assessment." Annual Review of Sociology 26, August: 611-39.

Bourdieu, Pierre, and John B. Thompson. 1991. Language and Symbolic Power. Cambridge, Mass.: Harvard University Press.

Brubaker, Rogers. 2004. Ethnicity without Groups. Cambridge, Mass.: Harvard University Press.

Bustamante, Rocío, Elizabeth Peredo, and María Esther Udaeta. 2005. "Women in the 'Water Wars' in the Cochabamba Valleys." In Vivienne Bennett, Sonia Dávila-Poblete, and María Nieves Rico, eds., Opposing Currents: The Politics of Water and Gender in Latin America. Pittsburgh, Pa.: University of Pittsburgh Press.

Butler, Judith. 1997. Excitable Speech: A Politics of the Performative. New York, N.Y.: Routledge.

Calhoun, Craig. 1991. "The Problem of Identity in Collective Action." In Joan Huber, ed., Macro-Micro Linkages in Sociology. Newbury Park, Calif.: Sage.

Comaroff, Jean, and John L. Comaroff. 1990. Ethnicity, Inc. Chicago, Ill.: University of Chicago Press.

Cramer Walsh, Katherine. 2012. "Putting Inequality in Its Place: Rural Consciousness and the Power of Perspective." American Political Science Review 106, no. 3: 517-32.

Crespo Flores, Carlos. 2003. Water Privatisation Policies and Conflicts in Bolivia: The Water War in Cochabamba (1999-2000). Oxford, UK: Oxford Brookes University.

Cusicanqui, Silvia Rivera. 1990. "Liberal Democracy and Ayllu Democracy in Bolivia: The Case of the Northern Potosí." Journal of Development Studies 26, no. 4: 97-121. 
Dunkerley, James. 1984. Rebellion in the Veins: Political Struggle in Bolivia, 195282. London, UK: Verso.

Eckstein, Susan, and Timothy P. Wickham-Crowley. 2003. Struggles for Social Rights in Latin America. New York, N.Y.: Routledge.

Edelman, Murray J. 1971. Politics as Symbolic Action: Mass Arousal and Quiescence. Chicago, Ill.: Academic Press.

Fraser, Nancy. 2013. "A Triple Movement? Parsing the Political Crisis after Polanyi." New Left Review 81 (May-June): 119-32.

Friedman, Jonathan. 1990. "Being in the World: Globalization and Localization." Theory, Culture, and Society 7, no. 2: 311-28.

Gamson, William A. 1992. Talking Politics. Cambridge, UK: Cambridge University Press.

García, Alberto, Fernando García, and Luz Quintón. 2003. La "Guerra del Agua": Abril de 2000, la crisis de la politica en Bolivia [The "water war:" April 2000, the crisis of politics in Bolivia]. La Paz, Bolivia: Fundación Programa de Investigación Estratégica en Bolivia.

George, Alexander L., and Andrew Bennett. 2005. Case Studies and Theory Development in the Social Sciences. Cambridge, Mass.: MIT Press.

Gerring, John. 2007. Case Study Research: Principles and Practices. New York, N.Y.: Cambridge University Press.

Gill, Lesley. 2000. Teetering on the Rim: Global Restructuring, Daily Life, and the Armed Retreat of the Bolivian State. New York, N.Y.: Columbia University Press.

Goffman, Erving. 1974. Frame Analysis: An Essay on the Organization of Experience. Cambridge, Mass.: Harvard University Press.

Goodwin, Jeff, and James M. Jasper. 2004. Rethinking Social Movements: Structure, Meaning, and Emotion. Lanham, Md.: Rowman \& Littlefield Publishers.

Gould, Deborah B. 2009. Moving Politics: Emotion and ACT UP's Fight against AIDS. Chicago, Ill.: University of Chicago Press.

Gould, Roger V. 1995. Insurgent Identities: Class, Community, and Protest in Paris from 1848 to the Commune. Chicago, Ill.: University of Chicago Press.

Gudeman, Stephen. 2001. The Anthropology of Economy: Community, Market, and Culture. Malden, Mass.: Blackwell.

Instituto Naciónal de Estadísticas. 2006. "Cochabamba: Estadisticas e Indicadores de Pobreza Según Sección Municipal, 2001.” [Cochabamba: Statistics and Indicators of Poverty According to Municipal Section, 2001] Available at http://www.ine.gov.bo, accessed February 20, 2007.

Kosek, Jake. 2006. Understories: The Political Life of Forests in Northern New Mexico. Durham, N.C.: Duke University Press.

Kurtz, Marcus J. 2004. "The Dilemmas of Democracy in the Open Economy: Lessons from Latin America.” World Politics 56, no. 2 (January): 262-302.

Larson, Brooke. 1998. Cochabamba, 1550-1900: Colonialism and Agrarian Transformation in Bolivia, exp. ed. Durham, N.C.: Duke University Press.

Laurie, Nina, and Simon Marvin. 1999. "Globalisation, Neoliberalism, and Negotiated Development in the Andes: Water Projects and Regional Identity in Cochabamba, Bolivia." Environment and Planning A 31, no. 8 (August): 1401-15.

Lofland, John. 1996. Social Movement Organizations: Guide to Research on Insurgent Realities. New York, N.Y.: Aldine de Gruyter. 
Loveman, Mara. 1998. "High-Risk Collective Action: Defending Human Rights in Chile, Uruguay, and Argentina." American Journal of Sociology 104, no. 2 (September): 477-525.

McAdam, Doug. 1999. Political Process and the Development of Black Insurgency, 1930-1970, 2nd ed. Chicago, Ill.: University of Chicago Press.

McAdam, Doug, John D. McCarthy, and Mayer N. Zald. 1996. Comparative Perspectives on Social Movements: Political Opportunities, Mobilizing Structures, and Cultural Framings. Cambridge, UK: Cambridge University Press.

McAdam, Doug, Sidney G. Tarrow, and Charles Tilly. 2001. Dynamics of Contention. Cambridge, UK: Cambridge University Press.

Noakes, John A., and Hank Johnston. 2005. "Frames of Protest: A Road Map to a Perspective." In Hank Johnston and John A. Noakes, eds., Frames of Protest: Social Movements and the Framing Perspective. Lanham, Md.: Rowman \& Littlefield.

Olivera, Oscar. 2004. Cochabamba! Water War in Bolivia. Cambridge, Mass.: South End Press.

Ostrom, Elinor. 1990. Governing the Commons: The Evolution of Institutions for Collective Action. Cambridge, UK, and New York, N.Y.: Cambridge University Press.

Oxhorn, Philip, and Graciela Ducatenzeiler. 1998. What Kind of Democracy? What Kind of Market? Latin America in the Age of Neoliberalism. University Park, Pa.: Pennsylvania State University Press.

Parkinson, Sarah. 2013. "Organizing Rebellion: Re-thinking High Risk Mobilization and Social Networks in War." American Political Science Review 107, no. 3 (August): 418-32.

Pearlman, Wendy. 2013. "Emotions and the Microfoundations of the Arab Uprisings." Perspectives on Politics 11, no. 2 (June): 387-409.

Peredo, Carmen, Carlos Crespo Flores, and Omar Fernández. 2004. Los regantes de Cochabamba en la guerra del agua: Presión social y negociación [The irrigators of Cochabamba in the water war: social pressure and negotiation]. Cochabamba, Bolivia: Centro de Estudios Superiores Universitarios-Universidad Mayor de San Simón.

Perreault, Tom. 2008. "Custom and Contradiction: Rural Water Governance and the Politics of Usos y Costumbres in Bolivia's Irrigators' Movement." Annals of the Association of American Geographers 98, no. 4 (September): 834-54.

Polanyi, Karl. 2001. The Great Transformation: The Political and Economic Origins of Our Time, 2nd ed. Boston, Mass.: Beacon Press.

Rabinow, Paul, and William M. Sullivan. 1987. Interpretive Social Science: A Second Look. Berkeley, Calif.: University of California Press.

Rioja Vasquez, Oswaldo. 2002. La Guerra del Agua. Documentary. Cochabamba, Bolivia.

Schelling, Thomas C. 1960. The Strategy of Conflict. Cambridge, Mass.: Harvard University Press.

Schwartz-Shea, Peregrine, and Dvora Yanow. 2012. Interpretive Research Design: Concepts and Processes. New York, N.Y.: Routledge.

Scott, James C. 1976. The Moral Economy of the Peasant: Rebellion and Subsistence in Southeast Asia. New Haven, Conn.: Yale University Press. 
Shultz, Jim. 2003. "Bolivia: The Water War Widens." NACLA Report on the Americas 36, no. 3 (January-February): 34-37.

Silva, Eduardo. 2009. Challenging Neoliberalism in Latin America. Cambridge, UK: Cambridge University Press.

Simmons, Erica. 2014. "Grievances Do Matter in Mobilization." Theory and Society 43, no. 5: 513-36.

Small, Mario. 2009. “'How Many Cases Do I Need?' On Science and the Logic of Case Selection in Field-Based Research.” Ethnography 10, no. 1 (March): 5-38.

Snow, David A., and Robert Benford. 1988. "Ideology, Frame Resonance, and Participant Mobilization.” International Social Movement Research 1, no. 1: 197-217.

- 1992. "Master Frames and Cycles of Protest." In Aldon D. Morris and Carol McClurg Mueller, eds., Frontiers in Social Movement Theory. New Haven, Conn.: Yale University Press.

Snow, David A., E. Burke Rochford, Steven Worden, and Robert Benford. 1986. "Frame Alignment Processes, Micromobilization, and Movement Participation." American Sociological Review 51, no. 4 (August): 464-81.

Snow, David A., and Sarah A. Soule. 2010. A Primer on Social Movements. New York, N.Y.: W. W. Norton.

Spronk, Susan J. 2007. "Roots of Resistance to Urban Water Privatization in Bolivia: The 'New Working Class,' the Crisis of Neoliberalism, and Public Services." International Labor and Working-Class History 71, no. 1 (Spring): 8-28.

Tarrow, Sidney G. 1998. Power in Movement: Social Movements and Contentious Politics, 2nd ed. Cambridge, UK: Cambridge University Press.

Thompson, E. P. 1971. "The Moral Economy of the English Crowd in the Eighteenth Century." Past E $\sigma^{\circ}$ Present, no. 50 (February): 76-136.

Tönnies, Ferdinand. 1988. Community E̋ Society. New Brunswick, N.J.: Transaction Books.

Wedeen, Lisa. 2002. "Conceptualizing Culture: Possibilities for Political Science." American Political Science Review 96, no. 4 (December): 713-28.

- 2008. Peripheral Visions: Publics, Power, and Performance in Yemen. Chicago, Ill.: University of Chicago Press.

_. 2009. "Ethnography as Interpretive Enterprise." In Edward Schatz, ed., Political Ethnography: What Immersion Contributes to the Study of Power. Chicago: University of Chicago Press: 75-93

Yashar, Deborah J. 2005. Contesting Citizenship in Latin America: The Rise of Indigenous Movements and the Postliberal Challenge. Cambridge, UK: Cambridge University Press. 